\title{
Relationship of Corporate Governance and Efficiency of Selected Public and Private Sector Banks in India
}

\author{
Anurag Agnihotri

\section{Sunil Gupta} \\ Dr, Assistant Professor, School of management, IGNOU, India
}

Dr, Assistant Professor, Department of Commerce, College of vocational studies, University of Delhi, India

\begin{abstract}
The business of banks runs on the public faith and their confidence in banks. The confidence level of the public can only be developed by proper disclosures and transparency. The good corporate governance practices ensure proper interest protection of all the stakeholders. The concept of corporate governance in case of banks differs from the corporate governance in other sectors. In banks, corporate governance must be supported by ethical leadership. The performance of banks is directly related to their leadership and size of the board. This paper is focusing on the level of corporate governance in the selected public sector and private sector banks and its impact on the NPA in banks. The problem in question for this paper was the role of corporate governance in the effective performance of public and private sector banks. So, this paper investigates the impact of corporate governance on the financial performance of banks, for example, on banks' efficiency to cater to the needs of public, innovations regarding product and services and about non-performing assets. The research methodology of this paper is based on primary and secondary sources. The primary sources include an unstructured interview of the managerial persons of selected banks. The primary data helped in understanding the different governance issues and problems in the banking sector. The secondary data is collected from the websites of concerned banks. The data collected with the help of primary and secondary data was analyzed with the help of statistical tools such as multiple regression model. The bank efficiency was calculated based on different factors such as board leadership structure, board composition, and board size. It was observed that the performance of any bank is closely related to corporate governance and ethical leadership of banks. It is found that among the corporate governance variables, smaller board size and a higher ratio of block ownership consistently seem to have better efficiency. However, other corporate governance variables do not have a significant and consistent impact on efficiency. There are a few factors, which could explain the weak system of corporate governance in India. The effectiveness of independent director provisions would be severely compromised in an environment where companies are run by autocratic leaders and in a culture where confrontations are generally avoided. However, certain variables related to management may not be measured such as ethical values of promoters and top-level management of public and private sector banks. There are many such examples in the Indian context and also in the globe. The paper has certain limitations such as all the banks in India were not studied so the results may be different when we include all the private and public sector banks. Further, it is suggested that the government and RBI as central banks should ensure effective governance in banks. The problem of NPA can be resolved by good corporate governance culture in banks.
\end{abstract}

Keywords: corporate governance, banking regulation, financial supervision, fiduciary duties.

JEL Classification: G34, L51, G21.

Cite as: Agnihotri, A., Gupta, S. (2019). Relationship of Corporate Governance and Efficiency of Selected Public and Private Sector Banks in India. Business Ethics and Leadership, 2(1), 109-117. http://doi.org/10.21272/bel.2(1).109-117.2019.

(C) The Authors, 2019. This article is published with open access at Sumy State University.

\section{Introduction}

The concept of corporate governance in real terms is to take care of all the stakeholders. The importance of corporate governance is more vivid in the banking sector as they are having the hard earn money of public deposited with them. The banks have a strong relation and impact on the economic development of any country as they provide the funds to corporate for their growth. This growth will provide jobs and earning opportunities for the population of those countries. The business of the banks runs on the faith and confidence of the public in these institutions. The corporate governance in general meaning is to take care of all the stakeholders of that company. However, in the banks, it is beyond the common understanding, which extends the public at large, 
ISSN (online) - 2520-6311; ISSN (print) - 2520-6761

the government, and other financial institutions. For the success of any bank, it is prerequisite that corporate governance must be supported by the ethical leadership as corporate governance can be implemented in the true sense by the ethical leadership of banks. The concept of corporate governance in case of banks differs from the corporate governance in other sectors but enough research in this area focusing the banks is not available. The problem we are discussing in this paper is to understand the role of corporate governance for the effective performance of banks. This paper is focusing on the level of corporate governance in selected banks and its impact on the NPA in banks.

The role of corporate governance in banks is more important as if it is not implemented properly then we will see the scams like Punjab National Bank (PNB), where one businessman Neerav Modi has taken away Rs. $11400 \mathrm{Cr}$. by misusing the SWIFT with the help of bank officials. Alexander (2006) explains that the corporate governance of banks is more important than in other industries because the banking sector plays a crucial financial intermediary role in any economy, particularly in developing countries. Even recently, RBI has issued the advisory to Kotak Mahindra Bank, Yes bank and Bandhan bank to reduce promoters shareholding in order to ensure better corporate governance in these banks. Poor corporate governance of the banks can drive the market to lose confidence in the ability of a bank to properly manage its assets and liabilities, including deposits, which could, in turn, trigger a liquidity crisis and then it might lead to an economic crisis in a country and pose a systemic risk to the society at large. The governance of banks is directly related to their performance. The governance in banks depends on the various subsets of corporate governance. It starts with top-level management for a policy framework and lower level management for effective implementation of corporate governance in any bank. In the light of PNB scam, it is important to examine the effect of corporate governance mechanisms in the banking sector and financial performance and bank efficiency. However, the problem of the researcher is that there is no study, which has been done on the impact of corporate governance on bank efficiency in the Indian context.

The performance of the banking system depends on identifying new products and selling them efficiently at a competitive price and ensure the protection of customer's interest. It is also essential for the overall growth of the economy since any lack of growth in efficiency will pull down India's economy.

Table 1. Gross NPA (in Rs.), Net NPA (in Rs.), Net NPA to Advance (\%), EPS, Dividend/Share, Net Profit/Share of banks for 2013-2018

\begin{tabular}{|c|c|c|c|c|c|c|c|}
\hline Bank & Year & $\begin{array}{l}\text { Gross NPA } \\
\text { (in Cr.) }\end{array}$ & $\begin{array}{l}\text { Net NPA (in } \\
\text { Cr.) }\end{array}$ & $\begin{array}{c}\text { Net NPA to } \\
\text { Advances } \\
(\%)\end{array}$ & $\begin{array}{c}\text { Diluted } \\
\text { EPS (Rs.) }\end{array}$ & $\begin{array}{l}\text { DPS } \\
\text { (Rs.) }\end{array}$ & $\begin{array}{c}\text { Net Profit/Share } \\
\text { (Rs.) }\end{array}$ \\
\hline AXISBANK & 2018 & 21280.48 & 8626.6 & 2 & 15.34 & 5 & 15.36 \\
\hline AXISBANK & 2017 & 6087.51 & 2522.14 & 1 & 34.4 & 5 & 34.51 \\
\hline AXISBANK & 2016 & 4110.19 & 1316.71 & 0 & 30.85 & 4.6 & 31.04 \\
\hline AXISBANK & 2015 & 3146.41 & 1024.62 & 0 & 132.23 & 20 & 132.33 \\
\hline AXISBANK & 2014 & 2393.42 & 704.13 & 0 & 118.85 & 18 & 110.68 \\
\hline AXISBANK & 2013 & 1806.3 & 1186.74 & 0 & 102.2 & 16 & 102.67 \\
\hline BANKBARODA & 2018 & 42719 & 18080 & 5 & 6 & 1.2 & 5.99 \\
\hline BANKBARODA & 2017 & 40521.04 & 19046.46 & 5 & -23.89 & 0 & -23.35 \\
\hline BANKBARODA & 2016 & 16261.44 & 8069.49 & 2 & 15.83 & 3.2 & 15.32 \\
\hline BANKBARODA & 2015 & 11875.9 & 6034.76 & 2 & 107.38 & 21.5 & 105.44 \\
\hline BANKBARODA & 2014 & 7982.58 & 4192.03 & $\frac{L}{1}$ & 108.84 & 21.5 & 106.05 \\
\hline BANKBARODA & 2013 & 4464.75 & 1543.64 & 1 & 127.84 & 17 & 121.41 \\
\hline CANBK & 2018 & 34202.04 & 21648.98 & 6 & 20.63 & 1 & 18.78 \\
\hline CANBK & 2017 & 31637.83 & 20832.91 & 6 & -53.61 & 0 & -51.8 \\
\hline CANBK & 2016 & 13039.96 & 8740.09 & 3 & 58.59 & 10.5 & 56.87 \\
\hline CANBK & 2015 & 7570.21 & 5965.46 & 2 & 54.48 & 11 & 52.86 \\
\hline CANBK & 2014 & 6260.16 & 5278.07 & 2 & 64.83 & 13 & 64.83 \\
\hline CANBK & 2013 & 4031.75 & 3386.31 & 1 & 74.1 & 11 & 74.1 \\
\hline FEDERALBNK & 2018 & 1727.05 & 941.2 & $\frac{1}{1}$ & 4.76 & 0.9 & 4.82 \\
\hline FEDERALBNK & 2017 & 1667.77 & 950.01 & 2 & 2.75 & 0.7 & 2.77 \\
\hline FEDERALBNK & 2016 & 1057.73 & 373.27 & 1 & 11.75 & 2.2 & 11.74 \\
\hline FEDERALBNK & 2015 & 1087.41 & 321.56 & 1 & 9.81 & 2 & 9.81 \\
\hline FEDERALBNK & 2014 & 1554.01 & 431.94 & 1 & 49 & 9 & 49 \\
\hline FEDERALBNK & 2013 & 1300.83 & 199 & 1 & 45.41 & 9 & 45.41 \\
\hline HDFCBANK & 2018 & 5885.66 & 1843.99 & 0 & 56.43 & 11 & 56.78 \\
\hline HDFCBANK & 2017 & 4392.83 & 1320.37 & 0 & 48.26 & 9.5 & 48.64 \\
\hline HDFCBANK & 2016 & 3438.38 & 896.28 & 0 & 41.67 & 8 & ד. ד. \\
\hline HDFCBANK & 2015 & 2989.28 & 820.03 & 0 & 35.21 & 6.85 & 35.34 \\
\hline HDFCBANK & 2014 & 2334.64 & 468.95 & 0 & 28.18 & 5.5 & 28.27 \\
\hline HDFCBANK & 2013 & 1999.39 & 352.33 & 0 & 21.91 & 4.3 & 22.02 \\
\hline ICICIBANK & 2018 & 42159.38 & 25216.81 & 5 & 16.77 & 2.5 & 16.82 \\
\hline
\end{tabular}


Table 1 (cont.). Gross NPA (in Rs.), Net NPA (in Rs.), Net NPA to Advance (\%), EPS, Dividend/Share, Net Profit/Share of banks for 2013-2018

\begin{tabular}{|c|c|c|c|c|c|c|c|}
\hline ICICIBANK & 2017 & 26221.25 & 12963.08 & 3 & 16.65 & 5 & 16.72 \\
\hline ICICIBANK & 2016 & 15094.69 & 6255.53 & 2 & 19.13 & 5 & 19.27 \\
\hline ICICIBANK & 2015 & 10505.84 & 3297.96 & 1 & 84.65 & 23 & 84.94 \\
\hline ICICIBANK & 2014 & 9607.75 & 2230.56 & 1 & 71.93 & 20 & 72.17 \\
\hline ICICIBANK & 2013 & 9475.33 & 1860.84 & 1 & 55.95 & 16.5 & 56.08 \\
\hline IDFCBANK & 2018 & 1542.1 & 576.47 & 1 & 2.98 & 0.75 & 3 \\
\hline IDFCBANK & 2017 & 3058.3 & 1139.04 & 2 & 2.34 & 0.25 & 1.38 \\
\hline IDFCBANK & 2016 & NA & NA & NA & -1164.79 & 0 & -516.98 \\
\hline INDUSINDBK & 2018 & 1054.87 & 438.9 & 0 & 47.56 & 6 & 47.95 \\
\hline INDUSINDBK & 2017 & 776.82 & 321.75 & 0 & 39.26 & 4.5 & 38.43 \\
\hline INDUSINDBK & 2016 & 562.92 & 210.48 & 0 & 33.41 & 4 & 33.88 \\
\hline INDUSINDBK & 2015 & 620.79 & 184.05 & 0 & 26.41 & 3.5 & 26.79 \\
\hline INDUSINDBK & 2014 & 457.78 & 136.76 & 0 & 21.4 & 3 & 20.3 \\
\hline INDUSINDBK & 2013 & 347.08 & 94.67 & 0 & 16.86 & 2.2 & 17.16 \\
\hline KOTAKBANK & 2018 & 3578.6 & 1718.1 & 1 & 18.55 & 0.6 & 18.53 \\
\hline KOTAKBANK & 2017 & 2838.11 & 1261.96 & 1 & 11.4 & 0.5 & 11.39 \\
\hline KOTAKBANK & 2016 & 1237.23 & 609.08 & 1 & 24.14 & 0.9 & 24.16 \\
\hline KOTAKBANK & 2015 & 1059.44 & 573.56 & 1 & 19.59 & 0.8 & 19.51 \\
\hline KOTAKBANK & 2014 & 758.11 & 311.41 & 1 & 18.24 & 0.7 & 18.23 \\
\hline KOTAKBANK & 2013 & 614.19 & 237.38 & 1 & 14.61 & 0.6 & 14.65 \\
\hline PNB & 2018 & 55370.45 & 32702.1 & 8 & 6.45 & 0 & 6.23 \\
\hline PNB & 2017 & 55818.33 & 35422.56 & 9 & -20.82 & 0 & -20.24 \\
\hline PNB & 2016 & 25694.86 & 15396.5 & 4 & 16.91 & 3.3 & 16.51 \\
\hline PNB & 2015 & 18880.06 & 9916.99 & 3 & 93.91 & 10 & 92.32 \\
\hline PNB & 2014 & 13465.79 & 7236.5 & 2 & 139.52 & 27 & 134.31 \\
\hline PNB & 2013 & 8719.62 & 4454.23 & 2 & 154.02 & 22 & 144 \\
\hline SBIN & 2018 & 112342.99 & 58277.38 & 4 & 13.43 & 2.6 & 13.15 \\
\hline SBIN & 2017 & 98172.8 & 55807.02 & 4 & 12.98 & 2.6 & 12.82 \\
\hline SBIN & 2016 & 56725 & 0 & 2 & 18 & 3.5 & 17.55 \\
\hline SBIN & 2015 & 61605 & 0 & 3 & 156.76 & 30 & 145.88 \\
\hline SBIN & 2014 & 51189.39 & 21956.48 & 2 & 210.06 & 41.5 & 206.2 \\
\hline SBIN & 2013 & 39676.46 & 15818.85 & 2 & 184.31 & 35 & 174.46 \\
\hline YesBANK & 2018 & 2018.56 & 1072.27 & 1 & 76.77 & 12 & 72.95 \\
\hline YesBANK & 2017 & 748.98 & 284.47 & 0 & 59.31 & 10 & 60.39 \\
\hline YesBANK & 2016 & 313.4 & 0 & 0 & 48.01 & 9 & 48.01 \\
\hline YesBANK & 2015 & 174.93 & 26.07 & 0 & 44.35 & 8 & 44.86 \\
\hline YesBANK & 2014 & 94.32 & 6.99 & 0 & 35.55 & 6 & 36.27 \\
\hline YesBANK & 2013 & 83.86 & 17.46 & 0 & 27.13 & 4 & 27.68 \\
\hline
\end{tabular}

Source: www.moneycontrol.com

The Indian banking system is a combination of large and small banks and the customers are also divided in to various categories based on their needs. Banks are engaged in mobilizing resources for the purpose of lending to foster growth and development. The Indian banking system consists of 27 public sector banks, 26 private sector banks, 46 foreign banks, 56 regional rural banks, 1,574 urban cooperative banks and 93,913 rural cooperative banks, in addition to cooperative credit institutions. Public-sector banks control more than 70 per cent of the banking system assets, thereby leaving a comparatively smaller share for its private peers. Banks are also encouraging their customers to manage their finances using mobile phones. In all banks, gross NPA (\%) is increasing in comparison with the last year's except Federal bank, HDFC Bank, IDFC Bank, IndusInd Bank and Yes Bank. Bank of Baroda, ICICI Bank, PNB, SBI banks have the highest level of NPAs. These banks, which are in high level of NPA, are contributing $1 / 3^{\text {rd }}$ portion to the total. Although various measures have been taken to address this issue with the IBC being the latest one where some of the larger NPAs have been identified for speedy resolution. In all banks, Net NPA (\%) is increasing in comparison with the last year's except Federal bank, HDFC Bank, IDFC Bank, IndusInd Bank, Kotak Bank, Yes Bank. EPS of HDFC Bank, IndusInd Bank, Yes Bank, are increasing year on year basis. Dividend/Share of HDFC Bank, IndusInd Bank, Yes Bank are increasing year on year basis. Net Profit/Share of HDFC Bank, IndusInd Bank, Yes Bank are increasing year on year basis. IDFC Bank also has incremental EPS, Dividend/Share and Net profit/Share. It can be said that the governance is a heart of any company, especially in the banking sector and looking the bank performance from efficiency aspect. Hence, the aim of this paper is to investigate the impact of corporate governance on financial performance of banks for example, on banks efficiency to cater the needs of public, innovations regarding product and services and about non-performing assets.

\section{Theoretical Framework}

The main theoretical assumption of this research is based on the agency framework. Agency theory argues for a clear separation of the responsibilities of the CEO and the chairman of the board and seems to prefer to have 
ISSN (online) - 2520-6311; ISSN (print) - 2520-6761

separate leadership structure because the day-to-day management of the company is led by the CEO, the chairman of the board needs to monitor the decisions made by the CEO which will be implemented by the management and to oversee the process of hiring, firing, evaluating and compensating the CEO (Brickley et al., 1997; Weir, 1997). If both are the same person, there would be no one to monitor his or her actions. It will be detrimental to the interest of all the stakeholders. The board composition is very important to effectively monitor the managers and reduce the agency cost. Although the executive directors have specialized skills, expertise and valuable knowledge of the firms' operating policies and day-to-day activities, there is a need for the independent directors to contribute the fresh ideas, independence, objectivity, and expertise gained in their own fields (Weir, 1997).

Jensen (1983) explained that boards with more than seven or eight members are unlikely to be effective. They elaborate that large boards result in less effective coordination, communication, and decision-making, and are more likely controlled by the CEO. Corporate governance could be viewed from three different perspectives; (a) managerial ownership, (b) block ownership, and (c) institutional ownership. Seifert et al. (2005), Le et al. (2006), Langnan, Steven and Weibin (2007) and Ramzi (2008) collectively agree on the important role of institutional shareholders in the monitoring of firms because of the following reasons; (a) institutional shareholders normally own a substantial number of shares, (b) the potential benefits from their activism is large enough to be worth their effort, (c) they have less ability than individual shareholders to liquidate the shares without affecting the share price, (d) substantial influence on the management, (e) they seem to have a fiduciary responsibility towards the ultimate owners, and (f) they have the ability to monitor executives since they are professionals.

\section{Research Methodology and Model}

Recent literature on corporate governance has tried to study its impact on the financial performance of banks, for example, on banks' efficiency. Jain and Thomson (2008) found that poor governance leads to poor financial performance. The following hypotheses will relate corporate governance and ownership variables with the financial performance of banks, in term of its efficiency.

$\mathrm{H}_{\mathrm{a} 1}$ : Bank efficiency is positively related to a separate leadership structure.

$\mathrm{H}_{\mathrm{a} 2}$ : Bank efficiency is positively related to a higher proportion of independent directors.

$\mathrm{H}_{\mathrm{a} 3}$ : Bank efficiency is negatively related to a board size.

$\mathrm{H}_{\mathrm{a} 4}$ : Bank efficiency is positively related to a higher proportion of director ownership, a higher proportion of block ownership and a higher proportion of institutional ownership.

The research methodology for this paper is primary and secondary both. The primary data was collected with the help of unstructured interview of the managerial persons at the concerned banks and secondary data is collected from the final accounts of the concerned banks. The data is analyzed with the tables and other statistical tools.

\section{Empirical Model and Sample Selection}

In this section, the empirical model of the study will be presented. The dependent variable is the efficiency of the banks, which is measured using two proxies; the ratio of non-performing loans to total loans (NPL_TL) and the ratio of operating expenses to total assets (OPEXP_TA). There are six independent variables, which comprise of three conventional measures of corporate governance (i.e. board leadership structure, board composition, and board size) and three measures of ownership structure (i.e. director ownership, institutional ownership, and block ownership). Finally, the empirical model of the study also includes four control variables; two control variables related to firm-specific characteristics (i.e. firm size and leverage), and two control variables related to economic environment (i.e. gross domestic product rate and economic crisis). The complete empirical model is as follows:

EFFICIENCY $=\beta_{+}+\beta_{1}$ BLS $\beta_{+} \beta_{2}$ INE_BZ $+\beta_{3}$ BZ $+\beta_{4}$ DOWN $_{+} \beta_{5}$ IOWN $_{+} \beta_{6}$ BOWN $_{+} \beta_{7}$ LNTA $_{+} \beta_{8}$ TD $_{-}$TE ${ }_{+} \beta_{9}$ GDP RATEx $_{9 i}+\beta_{10}$ DUM_CRISIS $+\varepsilon_{i t}$

Where:

EFFICIENCY = Performance is measured using two proxies; namely, the ratio of non-performing loans to total loans and ratio of operating expenses to total assets;

BLS $=$ Board leadership structure, where $1=$ separate leadership structure, and $0=$ combined leadership structure; 
INE_BZ $=$ Proportion of independent non-executive directors on the board;

$\mathrm{BZ}=$ Board size;

DOWN = Proportion of director ownership;

IOWN = Proportion of institutional ownership;

BOWN = Proportion of block ownership;

LNTA = Firm size, measured by Log of total assets;

TD_TE = Leverage, measured by total assets over total equity;

GDP RATE $=$ Gross domestic product growth rate;

DUM_CRISIS $=$ Dummy variable for economic crisis years, where $1=$ crisis year, $0=$ non-crisis year .

The sample includes the twelve listed banking companies since there are only twelve listed banks in India. Sample data have been collected from 2012 until 2018 because Indian Code on Corporate Governance (MCCG) was introduced in 2001 and data collection period is five years before and after introducing MCCG (2001). The total number of observations is 120 observations. However, some of the observations need to be dropped due to unavailability of data and some companies were not classified as banks in all the ten years' period. It left the final observations to 108 observations. Data were collected either from the annual reports of the companies or from Bloomberg. The statistical method used in this study is a panel data analysis (generalized least square method). The generalized least square method is used because the sample data are not normally distributed and the data have either heteroskedasticity problem, autocorrelation problem or both of them. According to Gujarati (2003), the usage of a generalized least square method will overcome all these problems.

\section{Data Analysis}

Under this section, the descriptive statistics will be explained first. It will be followed by the discussions on the GLS multivariate regression results on the relationship between bank efficiency and corporate governance variables. Table 2 shows the descriptive statistics of the variables used in the study. In case of board leadership structure, its mean value (0.81) shows that a majority of the companies have separate leadership structure although the minimum value (zero) shows that there are companies, which have combined leadership structure. Similar to the recommendation of the MCCG (2001), the sample mean value (0.36) shows that the ratio of independent directors is slightly more than one-third of the total number of the directors. The mean value (8.23) of board size shows the existence of quite a reasonable board size, e.g. Jensen and Ruback (1983) suggest that a board size of not more than 7 or 8 members is considered reasonable in ensuring effectiveness. For ownership, the mean values of director ownership and institutional ownership are 0.02 and 0.17 respectively. The ownership of shares by directors can be considered very low where, on average, only 2 percent of shares owned by the directors. On the other hand, institutional investors, on average, owned 17 percent of shares which could still be considered low although it is significantly higher than the ownership by the directors. In the case of block ownership, its mean value (0.53) shows that the significant portion of the shares is owned by large shareholders. The mean values of dependent variables are: for the ratio of non-performing loans to total loans (11.19) and the ratio of operating expenses to total assets (0.02). As for the firm-specific characteristics, the sample companies have the mean values of RM45992.19 millions for total assets and 344.73 for the ratio of total debt to total equity. Finally, the average GDP rate is 8 percent per annum.

Table 2. Descriptive Statistics Results

\begin{tabular}{|c|c|c|c|c|}
\hline CG variables & Mean & Std. Dev. & Min & Median \\
\hline BLS & 0.81 & 0.40 & 0.00 & 1.00 \\
\hline INE_BZ & 0.36 & 0.18 & 0.10 & 0.33 \\
\hline $\mathrm{BZ}$ & 8.23 & 2.34 & 4.00 & 8.00 \\
\hline \multicolumn{5}{|c|}{ (b) Ownership variables } \\
\hline DOWN & 0.02 & 0.05 & 0.00 & 0.00 \\
\hline IOWN & 0.17 & 0.18 & 0.00 & 0.09 \\
\hline BOWN & 0.53 & 0.21 & 0.00 & 0.58 \\
\hline \multicolumn{5}{|c|}{ (c) Efficiency variables } \\
\hline NPL_TL & 11.19 & 12.09 & 0.00 & 9.18 \\
\hline OPEXP_TA & 0.02 & 0.01 & 0.00 & 0.02 \\
\hline \multicolumn{5}{|c|}{ (d) Control variables } \\
\hline TA & 45992.19 & 40245.92 & 1120.36 & 33326.95 \\
\hline TD_TE & 344.73 & 331.14 & 14.03 & 223.80 \\
\hline GDP RATE & 0.08 & -0.05 & 0.02 & 0.09 \\
\hline
\end{tabular}

Source: Researcher output 


\section{GLS Results}

Efficiency is measured by two proxies, namely, ratio of non-performing loans to total loans and ratio of operating expenses to total assets. The findings for each will be explained in the following paragraphs.

\section{The Ratio of Non-performing Loans to Total Loans as a Proxy of Efficiency}

Table 3 shows the GLS results for the ratio of non-performing loans to total loans (i.e. NPL_TL). With regard to the corporate governance variables, only board size has a significant effect on banks' efficiency (at $\mathrm{p}<0.01$ ). The higher the ratio of non-performing loans to total loans, the lower will be the banks' efficiency. Therefore, a significant positive relationship between the board size and the ratio of non-performing loans to total loans means that a smaller board size influences better banks' efficiency. As for the ownership variables, higher ownership by the directors (i.e. DOWN) and more concentrated ownership (i.e. BOWN) lead to better banks' efficiency. The results could suggest that as directors own more shares of the company, the interests of shareholders are better aligned to the firms' interests. The significance of concentrated ownership could suggest better monitoring by the block holders. Finally, with regard to the control variables, bigger banks, better economic environment and financial crisis period lead to better banks' efficiency.

Table 3. GLS results of the ratio of non-performing loans to total loans

\begin{tabular}{|c|c|c|c|}
\hline & Coefficient & Z Statistics & $P$ value \\
\hline \multicolumn{4}{|l|}{ Independent variables } \\
\hline BLS & 0.17 & 0.12 & 0.90 \\
\hline INE_BZ & 5.16 & 1.25 & 0.21 \\
\hline $\mathrm{BZ}$ & 0.81 & $2.6^{*}$ & 0.01 \\
\hline DOWN & -39.89 & $-4.13^{*}$ & 0.00 \\
\hline IOWN & -5.05 & -1.62 & 0.11 \\
\hline BOWN & -7.23 & $-2.41 * *$ & 0.02 \\
\hline \multicolumn{4}{|l|}{ Control variables } \\
\hline LNTA & -2.16 & $-2.41 * *$ & 0.02 \\
\hline TD_TE & 0.00 & -0.19 & 0.85 \\
\hline GDP RATE & -32.09 & $-4.6^{*}$ & 0.00 \\
\hline DUM_CRISIS & -2.96 & $-2.6^{*}$ & 0.01 \\
\hline CONS & 32.24 & $4.33^{*}$ & 0.00 \\
\hline Chi2 & & & $71.17^{*}$ \\
\hline$P$ value & & & 0 \\
\hline Heteroskedastic & LR Chi2 & & $158.31 *$ \\
\hline (LR Test) & P value & & 0 \\
\hline Autocorrelation & F statistics & & $2361.29 *$ \\
\hline (Wooldridge Test) & $P$ value & & 0 \\
\hline
\end{tabular}

Source: Researcher output

\section{The Ratio of Operating Expenses to Total Assets as a Proxy of Efficiency}

Table 4 shows the GLS results for the ratio operating expenses to total assets (i.e. OPEXP_TA) which is the second proxy for efficiency. Overall, the GLS results of the second proxy of efficiency (i.e. OPEXP_TA) are much weaker as the $\mathrm{Chi}^{2}$ value is much lower (i.e. 29.58) than the GLS results of NPL_TL (Chi ${ }^{2}$ of 71.17). Consistent with the results in Table 3 , board size is still found to be significant (at $\mathrm{p}<0.10$ ). Institutional ownership (i.e. IOWN) is also found to be significant; however, the sign of relationship contradicts theoretical expectation. As for the control variables, only firm size is found to be significant. 
Table 4. GLS results of the ratio of operating expenses to total assets

\begin{tabular}{|c|c|c|c|}
\hline & Coefficient & Z Statistics & P value \\
\hline \multicolumn{4}{|l|}{ Independent variables } \\
\hline BLS & 0.00 & 0.02 & 0.99 \\
\hline INE_BZ & 0.00 & 0.17 & 0.86 \\
\hline $\mathrm{BZ}$ & 0.00 & 1.66 & 0.10 \\
\hline DOWN & 0.00 & 0.09 & 0.93 \\
\hline IOWN & 0.01 & $3.41 *$ & 0.00 \\
\hline BOWN & 0.00 & -1.45 & 0.15 \\
\hline \multicolumn{4}{|l|}{ Control variables } \\
\hline LNTA & 0.00 & $-2.50 *$ & 0.01 \\
\hline TD_TE & 0.00 & -0.16 & 0.87 \\
\hline GDP RATE & 0.00 & -0.45 & 0.65 \\
\hline DUM_CRISIS & 0.00 & 0.59 & 0.56 \\
\hline CONS & 0.03 & $5.35 *$ & 0.00 \\
\hline $\begin{array}{l}\text { Chi2 } \\
\mathrm{P} \text { value }\end{array}$ & & & $\begin{array}{l}29.58^{*} \\
0.00\end{array}$ \\
\hline $\begin{array}{l}\text { Heteroskedastic } \\
\text { (LR Test) }\end{array}$ & $\begin{array}{l}\text { LR Chi2 } \\
\text { P value }\end{array}$ & & $\begin{array}{l}80.30^{*} \\
0\end{array}$ \\
\hline $\begin{array}{l}\text { Autocorrelation } \\
\text { (Wooldridge Test) }\end{array}$ & $\begin{array}{l}\text { F statistics } \\
\text { P value }\end{array}$ & & $\begin{array}{l}25.41^{*} \\
0.00\end{array}$ \\
\hline
\end{tabular}

Source: Researcher output

Based on the GLS results of the two proxies of banks' efficiency, many conventional corporate governance and ownership structure variables, based on the agency framework, were found to be insignificant. Although agency theory represents an attractive platform for structuring corporate governance systems, the generalizability of such theory is seems rather restrictive. This theory seems to be Anglo-American centric, grounded in capitalistic theory (Mccarthy \& Puffer, 2008) and insensitive to non-economic forces that drive managerial choices in mixed (socialist/ capitalist) economies. Hence, it could be concluded that corporate governance systems are not converging and (Yoshikawa \& Phan, 2003) so local laws and local business environment might influence the governance system in its own country (Seifert et al., 2005). Furthermore, the agency theory focuses on the conflict between directors and owners but not between the majority and minority of shareholders. In India, the later conflict is the major problem and hence the applicability of agency theory in the Indian context is rather limited.

\section{Conclusions}

It is observed that the corporate governance plays a significant role in the performance of any bank and protects the interest of all stakeholders. The level of NPA and corporate governance is closely related to each other. The findings of this study have important implication for banks in India. It is found that among the corporate governance variables, a smaller board size and a higher ratio of block ownership consistently seem to have better efficiency. It is found that HDFC, ICICI scoring high in corporate governance. However, the rest of the corporate governance variables do not seem to have a significant and consistent impact on efficiency. There are a few factors, which could explain the weak system of corporate governance in India. The effectiveness of independent director provisions would be severely compromised in an environment where companies are run by autocratic leaders and in a culture where confrontations are generally avoided. Hence, a Western-style board may not work well within Indian culture. Further, it says that Good corporate governance seeks to achieve a balance between business and ethics, which means the process of achieving the business goals, has to be ethical and fair on all fronts. SBI failed to find a place among the top 10 companies in any of the eight parameters. It is true that the 'corporate governance' has no unique structure or design and is largely considered ambiguous. There is still lack of awareness about its various issues, like, social responsibility, business ethics, quality and frequency of financial and managerial disclosure, compliance with the code of best practice, roles and responsibilities of the Board of Directories, shareholders rights, etc. There have been many instances of failure and scams in the corporate sector, like collusion between companies and their accounting firms, the presence of weak or ineffective internal audits, lack of required skills by managers, lack of proper disclosures, noncompliance with standards, etc. As a result, both management and auditors have come under greater scrutiny.

The implementation of corporate governance norms in Indian banks has been phenomenal after the bank reforms were put in place. With the initial framework of the Ganguly committee, there has been a consistent 
Business Ethics and Leadership, Volume 3, Issue 1, 2019

ISSN (online) - 2520-6311; ISSN (print) - 2520-6761

focus on 'fit and proper' standards. The PSBs have even begun to rate their corporate governance standards from rating agencies. Banks have been working on the sustainability of corporate governance standards and have begun to realize the importance of corporate social responsibility, which is an integral part of it. The multiplicity of regulators, issues in the appointment of rightly qualified Board members and conflict of interest between the long term and short-term objectives always pose bigger challenges. Thus, it is recommended that regulatory authorities should make the rules for the effective implementation of corporate governance in the banks. It is also suggested that banks should develop a good corporate culture for effective implantation of corporate governance in banks.

\section{References}

1. Alexander, K. (2006). Corporate governance and banks: The role of regulation in reducing the principalagent problem. Journal of Banking Regulation, 2(1), 17-40.

2. Chen, Z., Cheung, Y.L., Stouraitis, A. \& Wong, A.W.S. (2005). Ownership concentration, firm performance, and dividend policy in Hong Kong. Pacific-Basin Finance Journal, 13(4), 431-449.

3. Choe, H. \& Lee, B.S. (2003). Korean bank governance reform after the Asian financial crisis. Pacific-Basin Finance Journal, 11(4), 483-508.

4. Chunxia, J., Shujie, Y. \& Zongyi, Z. (2009). The effects of governance changes on bank efficiency in China: A stochastic distance function approach. China Economic Review, 20(4), 717-731.

5. Cornett, M.M., Marcus, A.J., Saunders, A. \& Tehranian, H. (2007). The impact of institutional ownership on corporate operating performance. Journal of Non Banking and Finance, 31(6), 1771-1794.

6. Dwivedi, N. \& Jain, A.K. (2003). Corporate governance and performance of Indian firms: The effect of board size and ownership. Employee Responsibilities and Rights Journal, 17(3), 161-172.

7. Eisenberg, T., Sundgren, S. \& Wells, M.T. (1998). Larger board size and decreasing firm value in small firms. Journal of Financial Economics, 48(1), 35-54.

8. Fosberg, R.H. \& Nelson, M.R. (1999). Leadership structure and firm performance. International Review of Financial Analysis, 8(1), 83-96.

9. Fuerst, O. \& Kang, S.H. (2004). Corporate governance, expected operating performance, and pricing. Corporate Ownership \& Control, 1(2), 13-30.

10.Gujarati, D.N. (2003). Basic econometrics, viewed on 16 May 2008, http://imall.ntu. edu.sg/ ProductDetail.asp?ProductID=27477\&categoryName=ECON, accessed.

11.Hamim Syahrum, A.M., Syed Musa, A. \& Naziruddin, A. (2006). A conceptual framework for and survey of banking efficiency study. UNITAR E-JOURNAL, 2(2), 1-19.

12.Huther, J. (1997). An empirical test of the effect of board size on firm efficiency. Economics Letter, 54(3), 259-264.

13.Ihsan, I. \& M. Kabir, H. (2002). Cost and profit efficiency of the Turkish banking industry: An empirical investigation. The Financial Review, 37(2), 257-280.

14.Izah, M.T., Nor Mazlina, A.B. \& Sudin, H. (2009). Evaluating efficiency of Indian banks using data envelopment analysis. International Journal of Business and Management, 4(6), 96-106.

15.Izah, M.T. \& Sudin, H. (2008). Technical efficiency of the Indian commercial banks: a stochastic frontier approach. Banks and Bank Systems, 3(4), 65-72.

16.Jain, A. \& Thomson, D. (2008). Corporate governance, board responsibilities, and financial performance: The National Bank of Australia. Corporate Ownership \& Control, 6(2), 99 -113.

17.Jensen, M.C. (1993). The modern industrial revolution, exit and the failure of internal control systems. Journal of Finance, 48(3), 831-880.

18.Jensen, M.C. \& Meckling, W.H. (1976). Theory of the firm: Managerial behavior, agency costs and ownership structure. Journal of Financial Economics, 3(4), 405-360.

19.Jensen, M.C. \& Ruback, R. (1983). The market for corporate control: The scientific evidence. Journal of Financial Economics, 11(1-4), 5-50.

20.Langnan, C., Steven, L. \& Weibin, L. (2007). Corporate governance and corporate performance: some evidence from newly listed firms on Chinese stock markets. International Journal of Accounting, Auditing and Performance Evaluation, 4(2), 183-197.

21.Leng, A.C.A. (2004). The impact of corporate governance practices on firms' financial performance: Evidence from Indian companies. ASEAN Economic Bulletin, 21(3), 308-318.

22.Lensink, R., Meestars, A. \& Naaborg, I. (2008). Bank efficiency and foreign ownership: Do good institutions matter? Journal of Banking and Finance, 32(5), 834-844.

23.Mahadzir, I. \& Hasni, A.B. (2009). Impact of merger on efficiency and productivity in Indian commercial banks. International Journal of Economics and Finance, 1(2), 225-231. 
24.Mak, Y.T. \& Li, Y. (2001). Determinants of corporate ownership and board structure: Evidence from Singapore. Journal of Corporate Finance, 7(3), 235-256.

25.Mccarthy, D.J. \& Puffer, S.M. (2008). Interpreting the ethicality of corporate governance decisions in Russia: Utilizing integrative social contracts theory to evaluate the relevance of agency theory norms. Academy of Management Review, 33(1), 11-31.

26.Mohd. Azmi, O., Abdul Rahim, A.R., Rosylin, M.Y., M. Shabri, A.M. \& Mohd. Eskandar Shah, M.R. (2006). Efficiency of commercial banks in India, Asian Academy of Management. Journal of Accounting and Finance, 2(2), 19-42.

27.Mohammad Rizal, S. (2006). Legal transplantation and local knowledge: Corporate governance in India. Australian Journal of Corporate Law, 20(10), 1-29.

28.Ramzi, B. (2008). The influence of institutional investors on opportunistic earnings management. International Journal of Accounting, Auditing and Performance Evaluation, 5(1), 89-106.

29.Sufian, F. (2004). The efficiency effects of bank mergers and acquisitions in a developing economy: Evidence from India. International Journal of Applied Econometrics and Quantitative Studies, 1(4), 53-74.

30.Weir, C. (1997). Corporate governance, performance and take-overs: An empirical analysis of UK merges. Applied Economics, 29(11), 1465-1475.

31.Yoshikawa, T. \& Phan, P.H. (2003). The performance implications of ownership-driven governance reform. European Management Journal, 21(6), 698-706. 